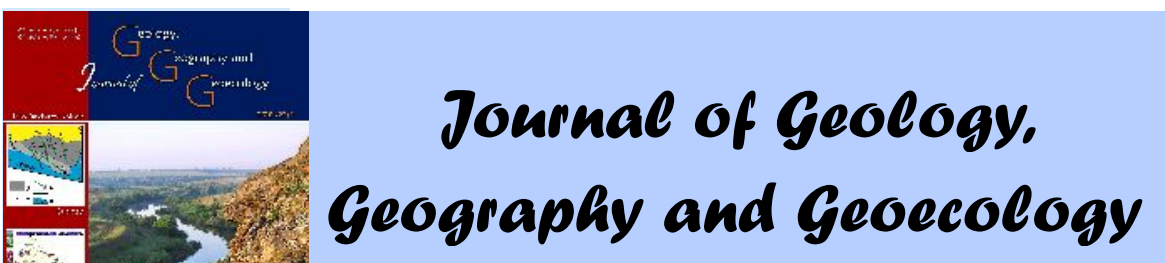

Journal home page: geology-dnu-dp.ua

Yevgrashkina G. P., Marchenko V. K.,

Tkachenko I. O., Korol O. I., Masenko A. V.

Journ.Geol.Geograph.Geoecology,27(1), 156-161

\title{
Ecological-hydrogeological history of the development of the coal industry in the Western Donbas under the influence of a complex of technogenic factors
}

\author{
G. P. Yevgrashkina, V. K. Marchenko, I. O. Tkachenko, O. I. Korol , A. V. Masenko
}

Dnipropetrovsk National University named after Oles Gonchar, Dnipro, Ukraine, e-mail: albinamasenko@gmail.com

Received 30.04.2018;

Received in revised form 18.05.2018;

Accepted 01.06.2018
Summary. The Western Donbas is a mining-manufacturing region of Ukraine with a potential for increasing coal extraction in the following years. The operation of mines is followed by intense water drainage of highly mineralized ground water which accumulates in tailing ponds, which were built in the ravines without barriers screening the water-containing rocks. The problem of rational usage and protection from contamination and exhaustion of all types of water sources available for practical usage is relevant for the studied region, and all around the world. The development of a fundamental scientific solution to this problem was started in 1986, when a constantly operating mathematical model (COMM) of the changes in hydrogeological conditions of the Western Donbas was developed. The authors were the Pavlohrad Geological-Survey Expedition (PGSE), the Dnipropetrovsk Affiliate of the Institute of Mineral Resources (DAIMR) and the Department of Geology and Hydrogeology of O. Honchar Dnipropetrovsk National University. It is a regional, multi-functional, constantly improved hydrogeological project limited in space but without a time limit. The COMM of the Western Donbas, along with the most obvious advantages, has one disadvantage. In spite of its small scale (1:100000), it provides only a general characteristic of technogenic changes in the ground water regime of the territory and cannot constitute a single scientific basis for developing nature-protection hydrogeologic measures. Therefore, it has been supplemented with mathematical models of the territories adjacent to the local objects of technogenic impact on the ground water. This includes tailing ponds, tailing dams, mining dumps and mine drainage. The first three types of technogenic objects have already been sufficiently studied and described in scientific publications (Eugrashkina , 2011 ; Eugrashkina , 2012; Eugrashkina , 2013; Eugrashkina, 2013). This paper focuses on the mathematical models, changes in hydrogeological conditions under the impact of the fourth factor mine drainage. The first three factors contaminate ground water, the fourth causes decreases in the operational reserves as a result of flow of the fresh water from the upper horizons to the productive dried-out layer.

Key words :mathematical model, theory of wells, regime observations, adequacy, cone of depression, ground water, nature-protection measures

\section{колого-гидрогеологическ я история р звития угольной промышленности п дного онб сс под влиянием комплекс техногенных ф кторов}

\footnotetext{
ніпропетровський н ціон льний університет імені леся онч $р$, ніпро, кр їн , e-mail: albinamasenko@gmail.com
}

. вгр шкін , . . рченко, . . к ченко, . . ороль, . . сенко

нот ція. хідний онб с - гірничодобувний регіон кр їни з перспектив ми збільшення видобутку вугілля у н ступні роки. ксплу т ція ш хт супроводжується інтенсивним відливом підземних вод підвищеної мінер ліз ції, які кумулюються у ст вк х - н копичув ч х, побудов них у 6 лк х без екр ніз ції водовмісної ч стини. пропонов ні як р дик льний з сіб охорони грунтів, поверхневих і підземних вод, вони ст ли джерелом їх з бруднення. ому проблем р ціон льного використ ння й охорони від з бруднення і висн ження усіх видів джерел води, прид тних для пр ктичного використ ння, кту льн для досліджув ного регіону, як і в усьому світі. унд мент льне н укове розв'яз ння цієї проблеми поч те в 1986 році створенням постійно діючої м тем тичної моделі (_ ) зміни гідрогеологічних умов « ірничодобувн ч стин хідного онб су». втори: влогр дськ геолого-розвідув льн експедиція ( ), ніпропетровське відділення нституту мінер льних ресурсів ( $\quad$ ) ік федр геології т гідрогеології імені леся онч р е регіон льн , б тофункціон льн , безперервно вдоскон люв н гідрогеологічн 3 д ч, обмежен у просторі і нескінченн уч сі. хідного онб су поряд із більшістю безсумнівних перев г м є один недолік. огляду їі дрібного м сшт бу (1: 100 000) вон д є лише 3 г льну x p ктеристику техногенних змін режиму підземних вод досліджув ної території і не може бути єдиною н уковою основою 
для розроблення природоохоронних з ходів гідрогеологічного спрямув ння. ому вон доповнен м тем тичними моделями територій, прилеглих до лок льних об'єктів техногенного впливу н підземні води. е ст вки - н копичув чі, хвостосховищ , ш хтні відв ли і ш хтний водовідлив. ри перші види техногенних об'єктів уже досить дет льно висвітлені у н укових публік ціях (Eugrashkina, 2011; Eugrashkina, 2012; Eugrashkina, 2013; Eugrashkina, 2013)]. н веденій ст тті розгляд ються м тем тичні моделі, зміни гідрогеологічних умов з впливу четвертого ф ктор ш хтного водовідливу. ерші три ф ктори 3 бруднюють підземні води, четвертий спричинює зменшення експлу т ційних з п сів через перетік ння прісних вод із верхніх горизонтів у продуктивні осушені товщі.

лючові слов :м тем тичн модель, теорія свердловин, режимні спостереження, декв тність, депресійн воронк, підземні води, природоохоронні з ходи.

Introduction. The objective of this research was creating and elaborating mathematical models of changes in the hydrogeological conditions of the territories in the zone of mine drainage impact. For scientific substantiation of nature-conservation hydrogeological procedures, we used the mathematical apparatus of the classic theory of single and connected boreholes in random spatial arrangement. The adequacy was proven by comparing the results of calculations with real conditions of operation and regime observations in the zone of mine drainage impact.

Material and methods. Chronologic sequence of the commissioning the mines and characteristic of their hydrogeological conditions is presented in Table 1 .

Table 1. Hydrogeological character of mines in Western Donbas

\begin{tabular}{|c|c|c|c|c|c|c|c|c|c|c|}
\hline № & 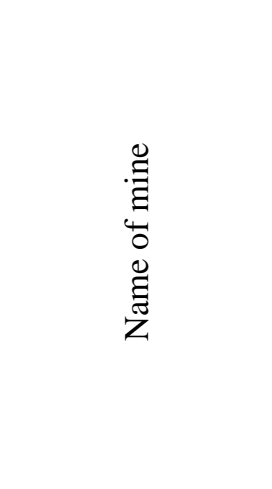 & 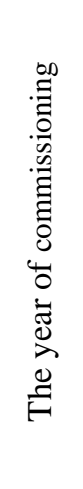 & 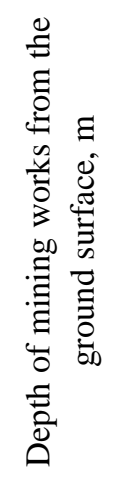 & 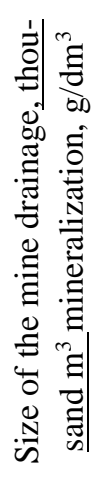 & 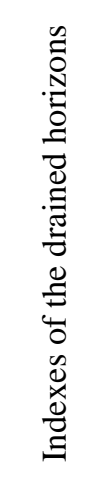 & 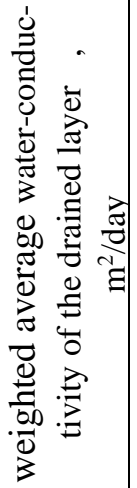 & 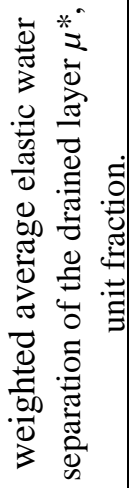 & 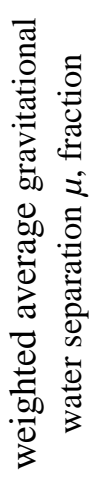 & 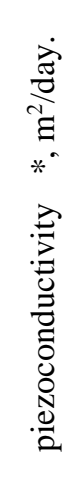 & 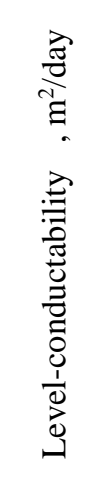 \\
\hline 1 & Pershotravenska & 1963 & $180-200$ & $\frac{12,33}{2,90}$ & $\mathrm{P}_{2}, \mathrm{C}_{\mathrm{IV}}$ & 132 & 0.009 & 0.1 & $\begin{array}{c}14 \\
666\end{array}$ & 1400 \\
\hline 2 & Ternivska & 1964 & 100 & $\frac{6,74}{2,6}$ & $\mathrm{P}_{2}, \mathrm{C}_{\mathrm{IV}}$ & 70 & 0.008 & 0.09 & 8750 & 778 \\
\hline 3 & Stepova & 1965 & $145-250$ & $\frac{21,0}{3,5}$ & $\mathrm{P}_{2}, \mathrm{C}_{\mathrm{IV}}$ & 140 & 0.009 & 0.1 & $\begin{array}{c}15 \\
556\end{array}$ & 1400 \\
\hline 4 & Pavlohradska & 1968 & 105 & $\frac{6,86}{6,3}$ & $\mathrm{P}_{2}, \mathrm{C}_{\mathrm{IV}}$ & 73 & 0.008 & 0.07 & 9125 & 1042 \\
\hline 5 & Yubilaina & 1970 & $180-230$ & $\frac{24,39}{2,21}$ & $\mathrm{P}_{2}, \mathrm{C}_{\text {IV }}$ & 161 & 0.009 & 0.11 & $\begin{array}{c}17 \\
888\end{array}$ & 1463.6 \\
\hline 6 & Blahodatna & 1971 & 115 & $\frac{7,7 \varepsilon}{15,0}$ & $\mathrm{P}_{2}, \mathrm{C}_{\mathrm{IV}}$ & 86 & 0.008 & 0.09 & $\begin{array}{c}10 \\
750\end{array}$ & 955.6 \\
\hline 7 & Samarska & 1973 & 160 & $\frac{8,81}{7,5}$ & $\mathrm{P}_{2}, \mathrm{C}_{\mathrm{IV}}$ & 80 & 0.007 & 0.08 & $\begin{array}{c}11 \\
428\end{array}$ & 1000 \\
\hline 8 & Dniprovska & 1975 & 260 & $\frac{5,34}{6,0}$ & $\mathrm{P}_{2}, \mathrm{C}_{\mathrm{IV}}$ & 42 & 0.006 & 0.09 & 7000 & 466.7 \\
\hline 9 & $\begin{array}{l}\text { Mine named after } \\
\text { the Heroes of Space }\end{array}$ & 1979 & 470 & $\frac{1,0}{37,1}$ & $\mathrm{C}_{\text {IV }}$ & 25 & 0.001 & 0.04 & 2000 & 625 \\
\hline 10 & Zahidno-Donbaska & 1980 & 585 & $\frac{1,13}{27,38}$ & $\mathrm{C}_{\mathrm{IV}}$ & 2 & 0.001 & 0.07 & 2000 & 285.7 \\
\hline 11 & Stashkov Mine & 1982 & 140 & $\frac{43,66}{2,66}$ & $\mathrm{P}_{2}, \mathrm{C}_{\mathrm{IV}}$ & 120 & 0.008 & 0.11 & $\begin{array}{c}15 \\
000\end{array}$ & 1090.9 \\
\hline
\end{tabular}


Analytical models are presented in Figs. 1-4. Development of the mathematical model of the eastern groups of mines (Fig. 1) was finished due to the decision to close the "Pershotravneva" mine. The model was published in an article co-written by the scientific supervisor (Eugrashkina and Marchenko, 2016). All epignostic [epignosis is a characteristic of hydrogeological process in the past - Translator's note] and predicting tasks were solved using the method of gradual changes in the steady states. The current studies were conducted independently for the group of mines in the Western Donbas. The basis of the mathematical models were the 2 methods - the abovementioned method of changes in the steady states conditions and the Theis fundamental solution modified for solution of this task.

The mathematical model for the group of mines - Pavlohradska, Blahodatna, Heroes of Space (Fig. 2) was developed after of the Pavlohradska Mine was put into operation in 1968. It worked as a "single well" to 1971, then the Blahodatna Mine was put into operation, making a mathematical series of first single, and then associated "wells". In 1979, the Mine named after Heroes of Space joined this group. Since then, all the mines created a model of three randomly located wells.

The mathematical models for the rest of the mines are in the stage of development (Fig. 3-4).

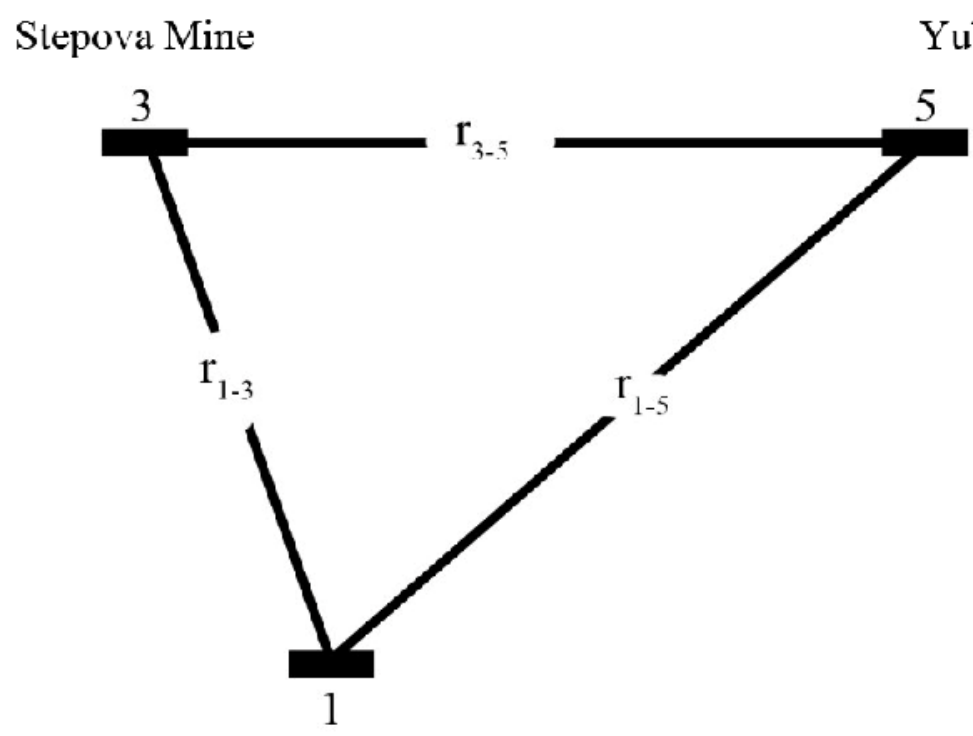

Pershotravenska Mine

Fig. 1. Model of locations of the eastern group of mines, scale: $1: 100000, r_{3-5}=4100 \mathrm{~m} ; \mathrm{r}_{1-3}=2200 \mathrm{~m} ; \mathrm{r}_{1-5}=4200 \mathrm{~m}$.

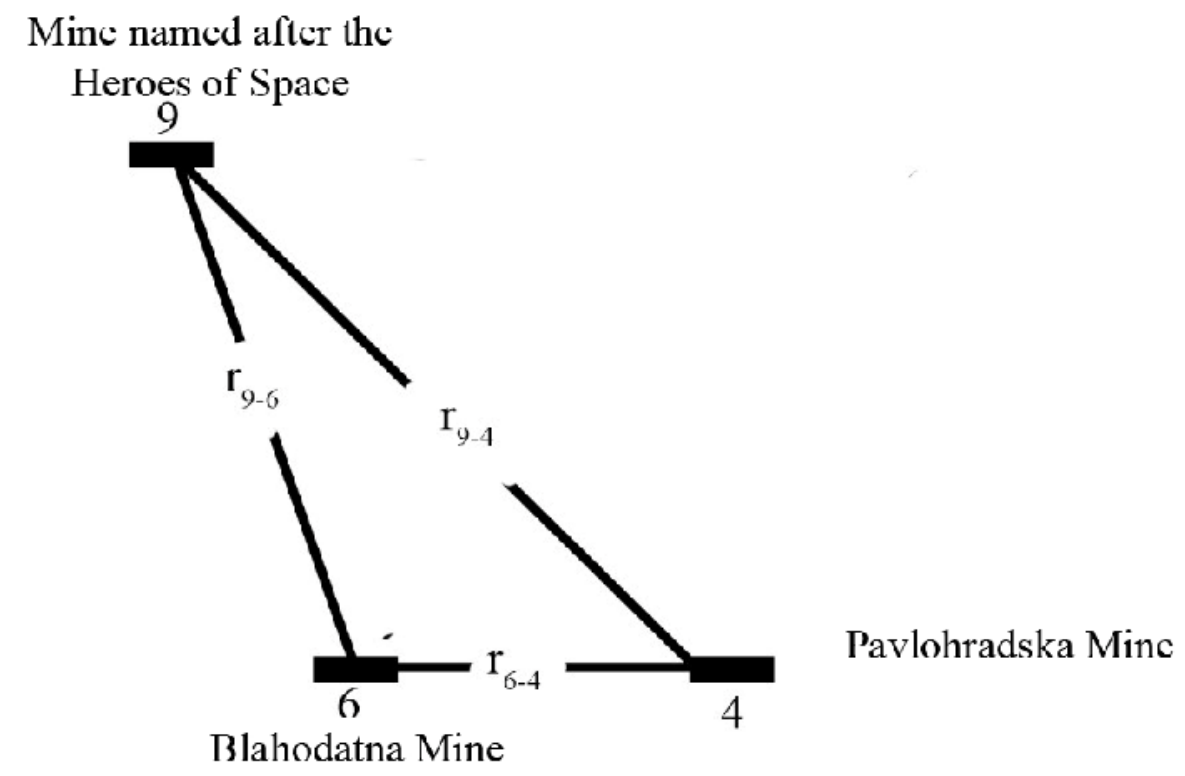

Fig. 2. The model of locations of the Mine named after Heroes of Space, the Blahodatna Mine, the Pavlohradska Mine, scale: 1:100 $000, \mathrm{r}_{-4}=4600 \mathrm{~m} ; \mathrm{r}_{6-4}=2500 \mathrm{~m} ; \mathrm{r}_{9-6}=2800 \mathrm{~m}$. 


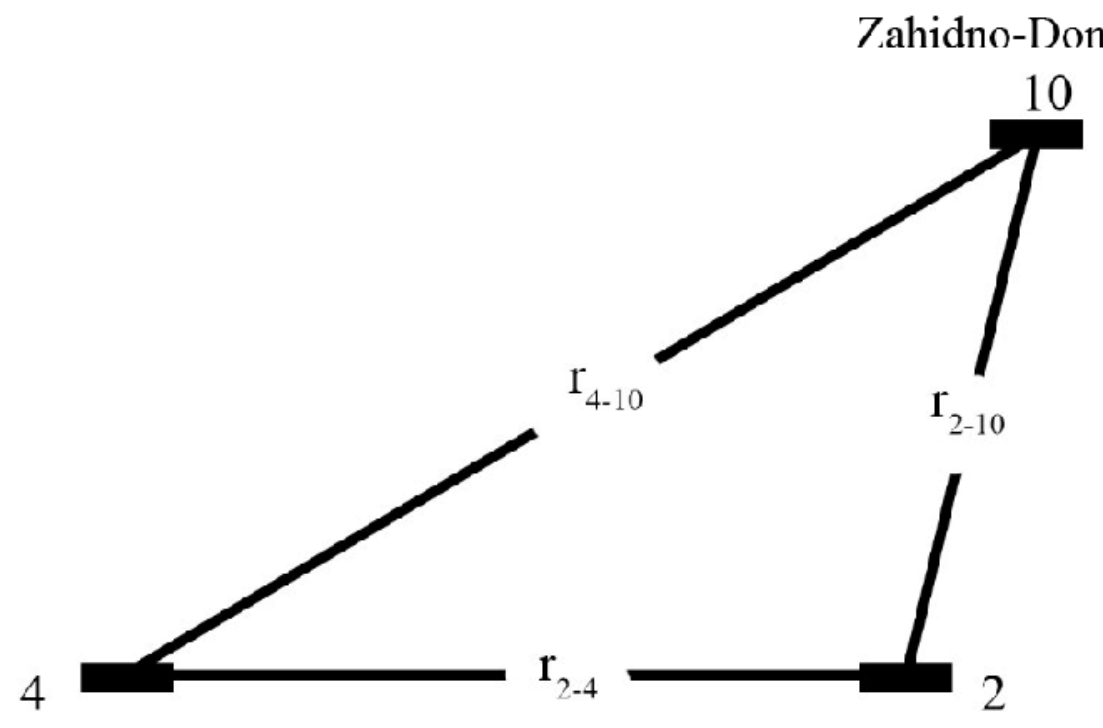

Pavlohradska Mine

Ternivska Mine

Fig. 3. The model of locations of the mines of the Zahidno-Donbaska, Pavlohradska, Ternivska, scale: 1:100 000, $\mathrm{r}_{2-4}=6300 \mathrm{~m}$; $\mathrm{r}_{2-10}$ $=2600 \mathrm{~m} ; \mathrm{r}_{4-10}=7750 \mathrm{~m}$. The Pavlohradska Mine is included in two models (Fig. 2, 3).

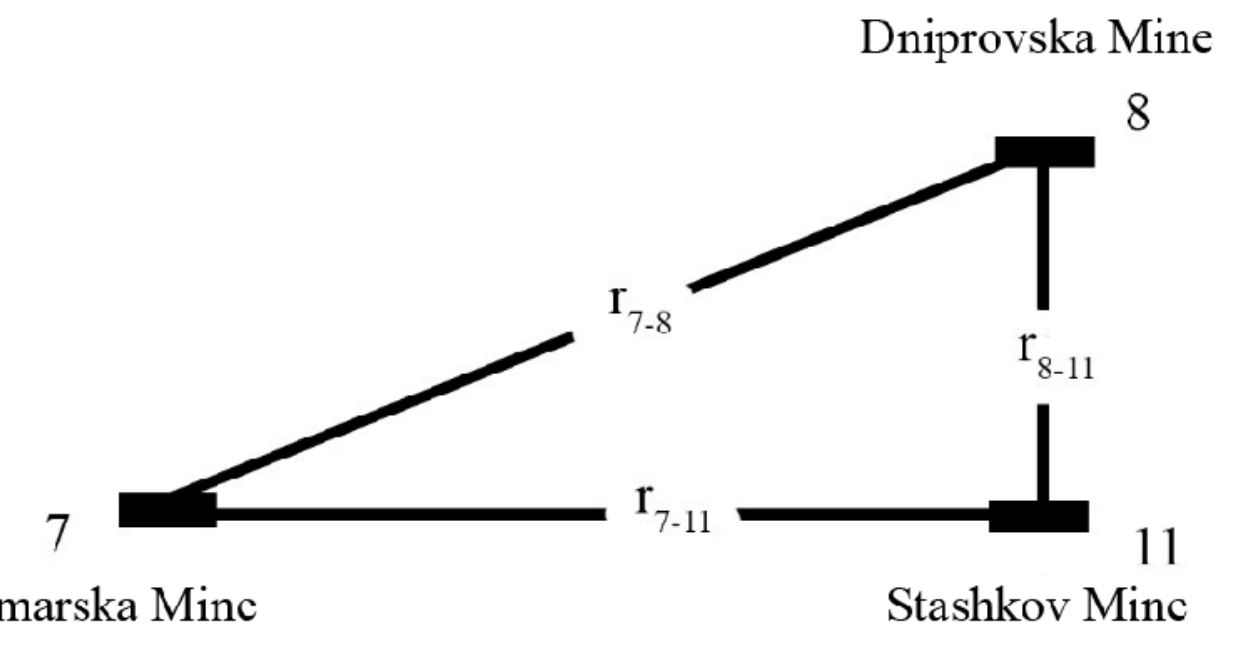

Fig. 4. The model of locations of the Samarska Mine ,the Dniprovska Mine, the Mine named after Stashkov, scale: 1:100 000, $\mathrm{r}_{7-8}=$ $8000 \mathrm{~m} ; \mathrm{r}_{8-11}=2000 \mathrm{~m} ; \mathrm{r}_{7-11}=8100 \mathrm{~m}$.

The model in Fig.2 chronologically characterizes in detail the change in hydrogeological conditions to 2020 inclusive.

The examples of solving the task of prediction and analysis of the results. According to the selected methods, for three associated "wells", the mathematical description of the water drainage processes at the end of 2020 looks as follows:

1. Method of gradual change in the steady states, Pavlohradska Mine, № 4 


$$
\begin{gathered}
\sum S_{4}=S_{4}+S_{4-6}+S_{4-9}=\frac{Q_{4}}{2 \pi T_{4}} \ln \frac{R_{4}}{r_{4}}+\frac{Q_{6}}{2 \pi T_{6}} \ln \frac{R_{6}}{r_{6}}+\frac{Q_{9}}{2 \pi T_{9}} \ln \frac{R_{9}}{r_{9}} \\
\sum S 4=\frac{6860}{2 * 3,14 * 79} \ln \frac{6670,73}{3,0}+\frac{7780}{2+3,14+86} \ln \frac{6201.17}{25.00}+\frac{1000}{2 * 3,14 * 25} \ln \frac{5297}{4600}=126 \mathrm{M} \\
R_{4}=1,5 \sqrt{a_{4} t_{4}}=6670,73 \mathrm{M} ; \\
R_{6}=1,5 \sqrt{a_{6} t_{6}}=6201,17 \mathrm{M} ; \\
R_{9}=1,5 \sqrt{a_{9} t_{9}}=5297 \mathrm{M} .
\end{gathered}
$$

2. Theis fundamental solution:

$$
\begin{gathered}
\sum S_{4}=\frac{Q_{4}}{4 \pi T_{4}} \ln \frac{2,25 a_{4} t_{4}}{r_{4}^{2}}+\frac{Q_{6}}{4 \pi T_{6}} \ln \frac{2,25 a_{6} t_{6}}{r_{4-6}^{2}}+\frac{Q_{9}}{4 \pi T_{9}} \ln \frac{2,25 a_{9} t_{9}}{r_{4-9}^{2}} \\
\sum S 4=\frac{6860}{4 * 3,14 * 73} \ln \frac{2,25 * 1042+52 * 365}{9}+\frac{7780}{4 * 3,14 * 86} \ln \frac{2,25+955 * 49 * 365}{6250000}+\frac{1000}{4 * 3,14 * 2} \ln \frac{2,25+285,7 * 41 * 365}{2116000}=125 \mathrm{M}
\end{gathered}
$$

The calculated decrease corresponds to the depth of the working area of the Pavlohradska Mine. This correspondence is a direct justification of the model's adequacy to real conditions. Analogical calculations of decreases were made for the Blahodatna Mine and the Mine of Heroes of Space with calculation of the numbers 6 and 9 respectively.

The expressions 1 and 2 contain the following symbols:

$\Sigma S_{4}$ - total water decrease in the mining shaft of Pavlohradska Mine (conventional number 4) $\mathrm{m}$;

$S_{4-6}-$ decrease caused by water drainage from the Blahodatna Mine, m;

$S_{4-9}-$ decrease caused by water drainage from the Mine of Heroes of Space, m;

$Q_{4}, Q_{6}, Q_{9}$ - water drainage of the corresponding mines, thousands $\mathrm{m}^{3} /$ day;

$r_{4}$ - radius of the Pavlohradska Mine shaft, $\mathrm{m}$;

$r_{4-6}, r_{4-9}$ - distance from the Pavlohradska to the Blahodatna Mine and the Mine of Heroes of Space, $\mathrm{m}$;

4, 6, 9- weighted average values of hydraulic conductivity of the water-bearing horizons of the drained layer in the mine sections, $\mathrm{m}^{2} /$ day;

$a_{4}, a_{6}, a_{9}-$ the corresponding level-conductivity, $\mathrm{m}^{2} /$ day;

$t_{4}, t_{6}, t_{9}$ - the duration of operation at the end of late 2020, years.

For the Blahodatna Mine and the Mine of Heroes of Space, the following results were obtained:

1. Method of gradual change in the stationary conditions:

$$
\Sigma \mathrm{S}_{6}=112,0 \mathrm{~m} ; \Sigma \mathrm{S}_{9}=450 \mathrm{~m} .
$$

2. Theis fundamental solution:

$$
\Sigma \mathrm{S}_{9}=111,0 \mathrm{~m} ; \Sigma \mathrm{S}_{9}=437 \mathrm{~m} .
$$

The difference between the factual and assessed depth of mining working areas is $1 \mathrm{~m}$ for the Blahodatna Mine, and $13 \mathrm{~m}$ for the Mine of Heroes of Space. The accuracy is high and indicates the correctness of the parameters and the selection of the methods. This difference in time should decrease, for classic hydrogeological processes always converge. Conclusions and recommendations on the problem investigated.

1.Four main factors of the negative impact on the regime, capacity and the quality of the ground water for drinking and technical supply are as follows: tailing ponds of the mine waste water, tailing dam of the central concentrating mill (CCM), mining dumps and the mine water drainage.

2.The first three factors contaminate the ground water, the fourth decreases its operational capacity by flowing down to the productive waterbearing horizons which have dried-out during the period of exploitation.

3.This factor is impossible to eliminate, for it is caused by natural geologic-hydrogeological conditions of the deposits.

4. he first and the second factors could be eliminated as follows: instead of the first pond and tailing dam, in each ravine, a cascade of three water reservoirs could be built. The discharge of low-mineralized water is made to the first one. It is used for irrigation with provision of substances for improving 
soil properties. The amount of these substances was calculated in accordance with the method of the Ukrainian Research Institute of Hydraulic Engeneering and Land Development. The second and the third water reservoirs are covered by a colloid-saline screen barrier. This is an invention of the Sokolovsky Ukrainian Research Institute of soil science and agrochemistry. The properties of such screen barrier to absorb salt and provide clean water to the waterbearing horizons. In the experimental variant, the screen barrier was successfully working for 5 years. This development can be improved in order to extend the term of operation of the required water filtration. After expiry of the control term, the water is released into the third pond, in the second pond the screen barrier is renewed. Thus, due to cleaning, the loss of water flow to the dried productive horizons is compensated.

5. For the third factor - mining dumps, efficient methods of recultivation have been developed and proposed by Oles Honchar DNU and Dnipro State Agrarian University.

Conclusions on the developed mathematical models of changes in the hydrogeological conditions in the zone of mine water drainage impact.

1. Classical theory of wells is a fundamental basis for developing mathematical models of mine water drainage.

2. The adequacy of the results of modeling to the real changes in the hydrogeological conditions is proved by comparing with the results of modeling, regime observations, made by the Prydniprovia Geological Survey Expedition.

3. Mathematical models allow highly accurate solving of the following tasks:

a) direct problems which characterize changes in the hydrodynamic pressures under the impact of the mine drainage in time and spaxe;

b) inverse tasks of determining and concretization of the hydrogeological parameters;

c) inductive tasks for substantiating the selection of an equation which describes the studied process and method of solving tasks.
4. The final goal of all types of studies is scientific substantiation of the complex of nature-protecting hydrogeological measures.

\section{References:}

Evgrashkina, G. P., Erchenko, M. A. 2013 Vibir ta obrrýntývannıa optımalnıh gidrogeologichnıh ýmov dlia variantý obvodnenogo shahtnogo vidvalý vilnogo zarostannıa na terıtoriï Zahidnogo Donbasý [Choice and substantiation of optimal hydrogeological conditions for a variant of a flooded dump of free overgrowing on the territory of the Western Donbas] Visn. Dnipropetr. Univ. Ser. Geol. Geogr., 15. 64 - 67 (in Ukrainian).

Evgrashkina, G. P., Sabash, O. E. 2012. Zakonomirnosti zminı gidrogeologichnıh ýmov na terıtoriï, prılegliı do hvostoshovia «Balka Stýkanova» ý Zahidnomý Donbasi [Patterns of changes in the hydrogeological conditions on the territory adjacent to the tailing ditch "Balka Stukanova" in the Western Donbass] Visn. Dnipropetr. Univ. Ser. Geol. Geogr., 14. 42 - 47 (in Ukrainian).

Evgrashkina, G. P., Sabash, O. E. 2013. Ekologo-gidrogeologichni problemı Zahidnogo Donbasý ta shliahı ïh virishennia [Ecological and hydrogeological problems of the Western Donbas and ways of their solution] Visn. Dnipropetr. Univ. Ser. Geol. Geogr., 15. 42 - 47 (in Ukrainian).

Evgrashkina, G.P., Zelenska, L. I. 2011. Zakonomirnosti zminı gidrogeologichnıh ýmov na terıtorii, prılegliı do stavka-nakopıchývacha skıdnıh shahtnıh vod «Balka Svidovok» ý Zahidnomý Donbasi [The regularities of the change of the hydrogeological conditions on the territory adjacent to the tailing pond of waste mine waters "Balka Vydivok" in the Western Donbass]. Visn. Dnipropetr. Univ. Ser. Geol. Geogr., Vol. 19, 13. 43 - 51 (in Ukrainian).

Evgrashkina, G. P., Marchenko, V. K. 2016 Geologogidrogeologicheska1a 1stori1a razvitı1a ýgolno1 promyshlennostı Zapadnogo Donbassa v matematıcheskıh modeliah [Geological and hydrogeological history of the development of the coal industry of the Western Donbass in mathematical models] Visn. Dnipropetr. Univ. Ser. Geol. Geogr., 24. 25 - 30 (in Ukrainian) 